\title{
What Challenges and Benefits Can Non-Formal Law and Language Integrated Learning Bring to University Students?
}

\author{
Anastasia Atabekova ${ }^{1}$, Rimma Gorbatenko ${ }^{1}$, Aleksandr Belousov ${ }^{1}$, Ruslan Grebnev $^{1} \&$ Olga Sheremetieva ${ }^{1}$ \\ ${ }^{1}$ Peoples' Friendship University of Russia, Moscow, Russian Federation \\ Correspondence: Anastasia Atabekova, Peoples' Friendship University of Russia, Moscow, 117198, Miklukho \\ Maklay st., 6, office 444, Russian Federation. Tel: 7-903-133-3907. E-mail: aaatabekova@gmail.com
}

$\begin{array}{lc}\text { Received: August 26, } 2015 & \text { Accepted: September 30, } 2015 \quad \text { Online Published: May 26, } 2016 \\ \text { doi:10.5539/ies.v9n6p62 } & \text { URL: http://dx.doi.org/10.5539/ies.v9n6p62 }\end{array}$

\begin{abstract}
The paper explores the ways in which non-formal content and language integrated learning within university studies can affect students' academic progress. The research has included theoretical and empirical studies. The article focuses on the observation of students' learning process, draws attention to challenges and benefits students experienced through non-formal Law and Language integrated learning. Emphasis is laid on those non-formal learning activities that may be viewed as part of the university students' training for their future professional activities. The paper provides the results of students' interviews and questionnaires revealing the issues that students consider important regarding non-formal content and language learning. The research findings aim to contribute to a better understanding of the overall interdependence of formal and non-formal learning within the university academic environment.
\end{abstract}

Keywords: non-formal learning, content and language integrated learning, university education

\section{Introduction}

The present research theme has been chosen due to a number of reasons.

First, the international community acknowledges the increasing awareness of the fact that formal education fails to respond to intensive technological, social and economic changes in society. Meanwhile non-formal education as part of lifelong learning helps young people and adults obtain and develop those skills and abilities that are necessary to meet the changing market requirements (Recommendation 1437 of Parliamentary Assembly of Council of Europe, 2000). Both Higher education policy makers and management are aware of the above state of affairs and are in search of effective ways to adapt their curricula to the industry and market needs. In this regard, non-formal learning might be applied as an instrument within the academic curriculum framework to overcome the gap between Academia educational standards and Market requirements.

With the respect to the above it seems suitable to specify the key concepts the present research has focused on. Education policy makers, legislators, administrators, and researchers have come to terms about ways to distinguish formal, non-formal, and informal learning with respect to administrative, organizational, legal, social parameters.

Formal learning (FL) takes place within the educational institutions under the academic program curriculum; FL is intentional, organized and structured by an institution according to the national educational requirements; FL ends up with a degree or qualification being awarded (Hodkinson et al., 2003). Informal learning (IFL) takes place by the learner's initiative alone and comes from everyday life activities; IFL is not organized and does not lead to a degree or qualification (Hodkinson et al., 2003). Non-formal learning, stands in-between the above two formats; it may be both intentional or unintentional, under the teacher's guidance or without any advice or supervision, outside the formal educational settings or provided within the institutional framework (Werquin, 2010). Scholars underline that "non-formal learning is organized and addressed to a particular subgroup of social community" (Coombs \& Ahmed, 1974, p. 8), and provide learners with alternative sources to those of the formal structured learning pathway (Cushion et al., 2010). Due to the above features, NFL has a flexible nature that makes it possible to implement it within varied educational formats. Thus, exploring NFL most efficient instruments to implement them within Higher education curricula might contribute to developing training standards in line with Industry and Market demands. 
Second, due to increasing international market integration and labor migration requirements to the competence in foreign languages is getting more sophisticated. The above competence as a foreign language mastery per si is not enough anymore. To compete successfully at the international level non-language university graduates are expected to be able to conduct full-scale professional activities in a foreign language. The above requires that educational institutions go beyond traditional foreign language classes in the curricula.

The past century witnessed a rise in research on Language for Specific Purposes theory and practice (LSP) that focused on the foreign language mastery stemming from learning language use in particular domains. Significant weight was attained to the use of language in appropriate contexts. Nevertheless, the new millennium draws attention to multilingual education for non-language students. The above leads to the shift from LSP to Content and Language Integrated Learning (CLIL) methodology that is applied primarily to non-language students'(whose degree does not cover foreign languages) training. CLIL assumes that both the subject and the foreign language are taught and learnt within a course framework. The term was coined in 1994 by David Marsh who specifies that CLIL represents a method of teaching "with dual-focused aims, namely the learning of content, and the simultaneous learning of a foreign language" (Marsh, 1994). Due to the above non-language university students get dual benefits as they obtain a degree in a certain professional domain and develop abilities to conduct professional activities in a foreign language. The mentioned benefits explain both policymakers and researchers' aspirations to integrate CLIL into the university curricula (Smit \& Dafouz, 2012; Watanabe et al., 2012).

Under the present circumstances, the study of university-based non-formal CLIL activities is expedient. The above-mentioned state of affairs has stipulated the present study that views it timely to enhance university-based non-language students' training with non-formal CLIL activities, covers issues regarding challenges, and benefits that non-formal CLIL can bring to university students in terms of their learning process and academic progress.

The research has limited the Content Learning to the Law field as the research team included the academic staff of the Law Institute of Peoples' Friendship University of Russia (Moscow, Russian Federation). As regards non-formal learning, the empirical analysis focused on varied students' extracurricular activities. PFUR Law Institute has long-standing experience in engaging students in extracurricular activities in foreign languages as part of students' creative development programs, volunteering projects, social activities, summer schools, participation in various contests, etc. These activities laid grounds to implement experimental non-formal learning as part of university-based training.

\subsection{Literature Review}

There is a considerable number of research papers and reports that aim to explore the specifics of formal, non-formal and informal learning (Colley et al., 2002; Livingstone, 2001; Schugurensky, 2000), and to explore the particular features of formal, non-formal and informal learning in various fields of knowledge (Ainsworth \& Eaton, 2010; Hodkinson, 2003). What is more projects on NFL practices and challenges have been conducted by various agencies under the international organizations umbrella including UNESCO (Carron \& Carr-Hill, 1991), Organisation for Economic Co-operation and Development (Werquin, 2010), European Center for Development of Vocational Training (CEDEFOP, 2009), European Trade Union Institute (Damesin et al., 2014), etc. Non-formal learning current state of affairs have been explored with regard to legislation, practice implementation and development through nations and continents, including Europe (CEDEFOP projects), Nothern and Southern America, Africa, Australia (Redvers-Lee, 2002; Eaton, 2011; Latchem, 2014; Singh, 2009). As regards the Russian Federation the legislation provides legal and administrative grounds for non-formal learning development, including its recognition, validation and accreditation issues (Federal Law, 2012), though implementation still lags behind as it requires increasing public awareness and promotion of the non-formal learning benefits for work skills development. Nevertheless, there is little information found on non-formal CLIL activities and the research findings and they mostly concern theoretical issues (Lindquist, 2012; Yasunaga, 2014). In this context the empirical research of positive experiences and challenging issues regarding students' perceptions on non-formal Law and Language integrated learning can contribute to identifying concrete instruments for effective implementation of the type of learning under study in the university curriculum with a view to update the overall university education in line with the market requirements.

The literature identifies a number of benefits of non-formal learning in terms of professional education and skills training. Scholars emphasize that non-formal learning accumulates and simulates professional activities, tasks, communication (Anderson et al., 1996). In this regard it seems timely to cite P. Werquin's statement that it is labor market that is a place for the production of non-formal and informal learning situations (Werquin, 2010, p. 5) as NFL takes its learning materials, settings, and context from particular professional environment. That is 
why researchers point out that NFL contributes to students' understanding of professional realities and tasks in quasi-professional situations of learning (Boud et al., 2000; Dehnbostel \& Molzberger, 2006; Fraser, 1995).

Besides, specialists underline that NFL helps to materialize tacit knowledge and implicit skills (Eraut, 2000) that are gained through practice, by observation and imitation. In this respect, NFL contributes to facilitating reflective learning in higher education (Brockbank \& Magill, 2007).

The above NFL benefits cannot be overestimated as employers report recruitment difficulties and say they are facing "skill shortage and skill mismatch that result from education systems training graduates of tomorrow in the skills needed in the industry of yesterday" (European Centre for the Development of Vocational Training, 2014, p. 1). Many employers are concerned that applicants "lack 'soft skills', such as interpersonal, communication and problem-solving abilities" (European Centre for the Development of Vocational Training, 2014, p. 1).The labor market requirements "push" researchers to argue for a holistic conceptualization of formal and non-formal learning (Nelson, 2006) and promote the idea of integrating the formal and non-formal learning for work skill development (Misko, 2008).

In this respect the empirical study of non-formal Law and Language integrated learning might help identify what non-formal activities in a foreign language in quasi-professional settings are more or less important, interesting, useful, challenging for students regarding their overall university-based learning progress, etc. This in turn would help the academic management and teaching staff to develop non-formal CLIL activities to coordinate university students' overall learning outcomes with market and industry needs.

As for administrative, legal, organizational challenges related to the non-formal learning, they include recognition, validation and accreditation standards that vary from country to country (Bowman et al., 2003). Non-formal learning through courses, seminars, summer schools within continuing professional development, vocational education, in-house specialists' training has more or less set standards that concern the relevant agency accreditation, validation of its non-formal learning activities provision and recognition of certificates (if any) that inform about NFL course field, length and place of learning. The respective documents contribute to students' portfolio and academic rating. Although the above practice leaves with no consideration many other activities of NFL that university, students might be involved in. Apart from seminars, courses as NFL forms outside the educational institution formal curriculum (Chester et al., 2005; Eaton, 2011), scholars also mention socio-cultural activities, volunteering projects (Dumitrescu, 1999). Nonetheless, in general currently no systematized list of university-based non-formal CLIL activities can be found either in research publications or in national educational agencies/ educational institutions regulations, recommendations, etc. Thus, the empirical research of non-formal CLIL activities of university students should try to map a tentative list of such activities and consider their possible documentary proof that might be relevant for both student's academic portfolio and potential employer.

Literature review reveals that one of critical issues regarding NFL is its assessment. CEDEFOP in its respective recommendations promote competence - based approach despite administrative differences across countries and underline the importance of flexible proof of qualifications and competences, utilization of a broader basis of competences, give the priorities to employers but not to ministries (CEDEFOP, 2009).

Both researchers and teachers underline that one of key tasks in NFL assessment is to gather evidence to prove that a student has obtained some kind of knowledge, skills and abilities that are necessary for or represent and reproduce some part of professional activities (Fokienè \& Sajienė, 2009). The above researchers specify that evidence should be based on practice-oriented activities and not just theoretical knowledge, should include samples of work performed and feedback from learners, peers, etc. Moreover the evidence should demonstrate sufficient level of competence in the field (Oleynikova, 2014; Sergeev, 2013). Nevertheless, literature provides mostly theoretical methodological information on NFL assessment (Zolotaryova, 2014). The respective state of affairs makes it up-to-date for the present empirical research to specify possible types of proof and samples on non-formal CLIL activities that might be relevant for students to demonstrate their professional competences and social maturity.

Another important aspect of NFL development is the use of technology to support the form of learning under study. Scholars underline that with regard to NFL the technology helps learners collect and use up-to-date information regarding professional labor market requirements, innovations, and development (Dodds, 1996).The academic environment traditionally use the technology (web-portals, educational clouds) as a storage tool for teaching aids and also as a means of communication and information. Although researchers underline that modern technologies should be more actively used in-group work (Dumitrescu, 1999). Thus, the present research should take into account the the current importance and prospects of technology use for non-formal CLIL activities. 
Special attention through literature review has been drawn to the CLIL phenomenon. Earlier in the introduction section the brief definition of CLIL has been provided. To move forward, it seems well timed to underline that CLIL is a content-driven learning, in which a foreign language is used for authentic interaction and inquiry (research). It is learning methodology in which a foreign language is 'the language of learning' (or target language), the 'language for learning' of content (vehicular language), and the 'language through learning', gained through negotiation of meaning occurring during social interaction and thinking (Coyle et al., 2010, pp. 36-37). The above explains why the CLIL development at both higher education and secondary school levels is considered one of key priorities within the global market multilingual development (Fortanet-Gomez, 2013; Naves, 2009; Wilkinson, 2004). The methodology under study provides students with opportunities to go beyond standard language skills mastery and acquire professional competencies in multilingual environment (Marsh et al 2011). Nonetheless, the literature review has revealed that despite plethora of publications on NFL, on the one hand, and CLIL, on the other, such issues as non-formal content and language integrated learning have not become the subject matter to the research analysis yet. That is why the present research aims to study non-formal CLIL phenomenon within the university studies with regard to students' academic progress, benefits and challenges.

\subsection{Research Questions}

The review of earlier and current research findings introduced in the section above, suggest that non-language students might benefit from non-formal CLIL activities. Thus, it appears well timed to formulate the following research questions:

- How does non-formal CLIL affect students' academic progress?

- What challenges may students face when involved in non-formal CLIL activities?

- What benefits may non-formal CLIL bring to students?

- What forms of non-formal learning may students benefit from most?

\section{Methodology}

\subsection{Research Stages}

The empirical research included observation and evaluation of students' progress and perceptions pertaining to non-formal CLIL mode of training, students' interviews.

At the first stage, it was necessary to draft the list of non-formal CLIL activities related to students' law and language integrated university-based education. The list took into account the literature review findings though mostly resulted from long-standing practice at PFUR Law Institute to engage students in extracurricular activities related to quasi-professional administrative, organizational and legal projects in foreign languages. The list included the following:

- $\quad$ participation in student conferences on Law in foreign languages;

- participation in theme-focused events conducted in foreign languages ( Christmas party, Women's day, Easter ceremony, Translator's day, Lawyer's day, etc.);

- $\quad$ articipation in contests for law students performed in foreign languages;

- volunteer projects to serve the international forums that are held at Moscow-based organizations and agencies;

- volunteer legal translator and interpreter projects to meet Moscow corporate and governmental agencies' needs;

- guiding foreign guests that arrive at the PFUR university to collaborate in law-related activities;

- conducting master classes in foreign languages for schoolchildren from secondary schools that participate in the program of prior professional knowledge orientation development;

- taking international exams in foreign languages.

It should be mentioned that the above activities in most cases are supported by the documentary evidence of the student's competence and work. The relevant proof contribute to students' academic rating as under the current PFUR regulations the student's academic progress in the subject is measured by scores for various learning activities including self-studies, class attendance and activities, tests, projects, etc. The student is supposed to get some percentage of scores through extracurricular activities related to the subject study (i.e. conference participation, some extra curriculum course attendance, etc.). The above listed NFL CLIL activities also add 
value to students' portfolio as the relevant proof confirm the students' social activity, aspiration to go beyond academic curriculum to enhance his/her one's abilities in real professional world, etc. The NFL CLIL activities might be proved by the following documents:

- conference paper publication (scientific supervisor's written recommendation is a prerequisite for the publication);

- certificate of participation/ diploma of winner in contests and other social events related to language and law;

- international exam/language school certificates;

- letters of thanks from outside agencies and institutions for volunteering activities;

- electronic or video records of CLIL activities, such as presentations, videos on law and language issues prepared by the students themselves and evaluated by the teacher.

At the second stage students were informed (at the schooling year start) about possible non-formal learning activities and offered to participate though it was not obligatory. Students were invited to take part in extra curriculum activities to enhance their competence in law, foreign language for legal purposes integrated professional competence, besides having the fixed workload of the foreign language for legal purposes training, and law subjects under the university academic program curriculum.

For the experiment purposes, the research team identified those students who preferred to limit their learning to classroom activities and home task performance, on the one hand, and those learners who showed their readiness to engage in extra curriculum non-formal CLIL activities, on the other.

Two learning "streams" were arranged. The first group included students who learnt Law and Language within standard academic curriculum and did not participate in non-formal CLIL activities. The second group combined formal learning and non-formal content and language integrated learning through activities listed above.

The next stage included the analysis of students' academic progress. Students' academic progress within the formal learning framework in both language skills (speaking, understanding, writing, reading, translation) and law subjects was observed and compared throughout the schooling year. Academic progress was measured according to the University standard procedure that included the amount of scores that students got and accumulated through the semester for self-studies, class attendance and activities, tests, projects, midterm and final term tests, extracurricular activities. The 100-score scale was arranged into excellent, good, satisfactory and poor marks. The academic progress observation included the analysis of students' marks on law subjects and on the language course. Formal final assessment was conducted in the form of test during the midterm and in form of the exam at the end of term.

A further stage included interviews, and open-ended questionnaires that were conducted at the schooling year-end within 2-year-long period to identify students' self-perceptions regarding the degree of interest and needs for non-formal CLIL activities. Only students who participated in non-formal integrated Law and Language activities were engaged in the above interviews and questionnaires. Interviews were aimed to identify those challenges and benefits that students preferred to specify regarding their non-formal CLIL activities. Students were interviewed individually and were asked about challenges they faced and benefits they considered obvious through their NFL. Open-ended questionnaires were conducted to identify those non-formal Law and Language integrated learning forms from which students benefited most. The questionnaires focused on every form of non-formal CLIL activities specified in the section with respect to the first stage of empirical research. The questions were structured in the following way (sample question on student conference): Did you participate in student conferences on Law in foreign languages? Yes/No. Did you consider it useful? Why?

\subsection{Research Participants}

Totally 168 Law students of BA program were engaged in the experiment. 84 students participated in the standard Formal academic learning, 84 students participated in combined formal and non-formal Law and Language integrated learning.

As it has been mentioned in the previous subsection students were invited to participate in the experiment on the voluntary basis, and it was each student's individual choice to be a member of the formal or combined (formal + non-formal) CLIL activities. Moreover, only those students who agreed to disclose their personal information under the participants' selection criteria were engaged in the experiment. Further, on the participants selection procedure took place.

The research team followed the current practices (see, for instance, Reason, 2003, Cabezudo et al., 2008, pp. 
22-23) and included in the criteria list students' socio-economic background (family income), geographical origin (students who were brought up in the capital/students who were brought up in other Russian regions), students' gender, cultural affiliation (Asian/Western culture), age. The above criteria reflected the University students' heterogeneous community as apart from about 140 countries from which the PFUR annually enrolls students, in Russia alone there live representatives of more than 80 nationalities.

As it was mentioned before the selection procedure resulted in two student subdivisions (only formal learning and combined formal and non-formal CLIL learning). Each subdivision included a balanced proportion of students in terms of the above listed criteria, including various level of academic achievements; in each subdivision there were students aged 19-20.

Besides, students' prior academic year data regarding progress in foreign languages and law subjects were thoroughly analyzed. The consideration of the above data also helped to arrange balance of students with various academic record within various learning groups.

To analyze the ways in which non-formal CLIL could affect students' academic progress the research team arranged and filled in students' individual files to record learners' progress and perceptions.

\subsection{Data Collecting and Statistic Processing Methods}

As to the data collecting and processing methods the research combined quantitative and qualitative methods, included statistical data processing and its interpretation, learning process observation, interviews and questionnaires consideration. Cluster, discriminant, factor analyses and correlation analysis were applied. The cluster analysis was used to identify the clusters regarding students' academic progress. The factor analysis was applied to outline those challenges and benefits that students considered relevant when reflecting on the non-formal law and language integrated non-formal learning. The independent $t$-test was used to determine statistically significant differences. SPSS was used for statistics data processing.

\section{Research Results}

\subsection{How Could Non-formal Learning Affect Students' Progress in Language and Law Integrated Learning?}

The students' academic progress in language and law integrated learning concerning their involvement or not involvement in additional non-formal learning was measured throughout the schooling year. The cluster analysis resulted in identifying various clusters that mapped students' academic progress (Table 1).

The combination of marks given to students on law subjects and legal language within formal learning and combined formal and non-formal learning resulted in 12 clusters for both formal learning and for combined learning at the academic year start. Nevertheless, it ended up with 6 and 4 clusters, respectively. The figures show positive potential of formal and combined formal and non-formal learning regarding the educational task to increase the homogeneity of the learning group's academic records throughout studies. Although non-formal learning appears to contribute to a stronger homogeneity of the students' learning community as the total number of formal learning clusters went down twofold, while the respective number of clusters regarding combined formal and non-formal learning went down threefold (from 12 to 6 , and from 12 to 4 , respectively).

Emphasis should be laid on the positive dynamics of cluster density regarding the clusters mapping the percentage of students who got only excellent or only good marks on all subjects, as well as those who got excellent marks on legal subjects and the good mark on the legal language. The feature concerns both students involved in purely formal and combined formal and non-formal learning.

Table 1. Clusters mapping students' academic progress in strict formal learning environment (FL) and combined formal and non-formal learning (NFL) environment

\begin{tabular}{|c|c|c|c|c|c|c|c|c|c|}
\hline \multirow{3}{*}{\multicolumn{2}{|c|}{$\begin{array}{c}\text { Students' academic progress } \\
\text { Academic year } \\
\begin{array}{c}\text { Marks on legal subjects and } \\
\text { legal language }\end{array} \\
\end{array}$}} & \multicolumn{8}{|c|}{ Percentage of students } \\
\hline & & \multicolumn{4}{|c|}{$1^{\text {st }}$ Term } & \multicolumn{4}{|c|}{$2^{\text {nd }}$ Term } \\
\hline & & \multicolumn{2}{|c|}{$\begin{array}{c}\text { Midterm } \\
\text { assessment }\end{array}$} & \multicolumn{2}{|c|}{$\begin{array}{c}\text { Final } \\
\text { assessment }\end{array}$} & \multicolumn{2}{|c|}{$\begin{array}{c}\text { Midterm } \\
\text { assessment }\end{array}$} & \multicolumn{2}{|c|}{$\begin{array}{c}\text { Final } \\
\text { assessment }\end{array}$} \\
\hline & $\begin{array}{l}\text { Formal }(F L) \text { or Formal and } \\
\text { non-formal }(F+N F) \text { learning }\end{array}$ & $F L$ & $F L+N F L$ & $F L$ & $F L+N F L$ & $F L$ & $F L+N F L$ & $F L$ & $F L+N F L$ \\
\hline 1 & $\begin{array}{l}\text { Excellent marks on legal subjects } \\
\text { and legal language }\end{array}$ & 3 & 4 & 7 & 12 & 10 & 20 & 13 & 27 \\
\hline
\end{tabular}


Excellent marks on legal subjects

2 and the good mark on the legal language

Excellent marks on legal subjects

3 and the satisfactory mark on the legal language

Excellent marks on legal subjects

4 and the poor mark on the legal language

Good marks on legal subjects and

5 the excellent mark on the legal language

Good marks on legal subjects and

6 the good mark on the legal language

Good marks on legal subjects and

7 the satisfactory mark on the legal language

Good marks on legal subjects and

8 the poor mark on the legal language

Satisfactory marks on legal

9 subjects and the excellent mark on the legal language

Satisfactory marks on legal

1 1 subjects and the good mark on the legal language

Satisfactory marks on legal

1 subjects and the satisfactory mark on the legal language

Satisfactory marks on legal

1. subjects and the poor mark on the legal language

Poor marks on legal subjects and

1. the satisfactory mark on the legal language

Poor marks on legal subjects and

34

$4 \quad 8 \quad 7$

$10 \quad 20$

$10 \quad 18$

22

20

$0 \quad 0$

$0 \quad 0$

11

$0 \quad 0$

$0 \quad 0$

$\begin{array}{ll}0 & 0\end{array}$

23

14

$0 \quad 3$

$0 \quad 0$

$30 \quad 30$

$32 \quad 42$

$35 \quad 42$

$38 \quad 42$

$24 \quad 24$

$21 \quad 12$

210

190

$0 \quad 0$

$0 \quad 0$

$0 \quad 0$

$0 \quad 0$

21

$$
0
$$

$0 \quad 0$

$0 \quad 0$

33

31

30

20

$23 \quad 22$

$21 \quad 16$

$21 \quad 15$

$18 \quad 13$

53

50

$\begin{array}{ll}0 & 0\end{array}$

$0 \quad 0$

$\begin{array}{ll}0 & 0\end{array}$

$0 \quad 0$

$0 \quad 0$

$0 \quad 0$
1. the poor mark on the legal language

Total clusters

22

$12 \quad 12$

$0 \quad 0$

$0 \quad 0$

Nonetheless, the most striking differences regarding students' academic progress in the above formats are concerned with the following figures in respect to final clusters density.

The percentage of students who got only excellent marks on all subjects went up fourfold in the formal learning environment and nearly sevenfold in the combined formal and non-formal learning environment.

The percentage of students who got excellent marks on legal subjects and the good mark on the legal language went up threefold in the formal learning environment and fourfold in the combined formal and non-formal learning environment.

The percentage of students whose academic record was spoiled by the satisfactory mark on the legal language went down by $5 \%$ among students who studied in the formal learning environment and "vanished" to 0 level from $24 \%$ among students who combined formal and non-formal learning.

Mention should be made that the clusters with inconsistent marks on legal subjects and legal language (for instance, clusters, mapping students who during the $1^{\text {st }}$ midterm assessment got excellent marks on legal subjects and the satisfactory mark on the legal language) went out of existence within the learning environment. 
The overall percentage regarding students' academic progress across the academic year was not sensitive to students' social-economic background/cultural affiliation/geographical origin/gender or age though it reflected the difference between students in view of their mode of studies.

The discriminant analysis demonstrated as statistically significant $\left(\lambda=0.123, \chi^{2}=4.00, p<0.01,89 \%\right.$ of matches belonging to the class) students' inclusion into the subdivision of combined non-formal and formal law and language integrated learning.

\subsection{Challenges Students Faced When Involved in Non-Formal Law and Language Integrated Learning}

The factor analysis helped identify the following list of challenges students faced when being involved in non-formal Law and Language Integrated Learning. The factor analysis helped to identify those challenges that students faced when being engaged in the non-formal law and language activities (the list is arranged in descending order of items importance, according to students' opinions):

1st factor-lack of student's awareness of the potential and importance of non-formal law and language integrated learning (0.879), $86 \%$ of the respondents mentioned the item;

2nd factor-lack of systematized information regarding activities for student's possible non-formal learning in the above integrated fields in the professional world outside the "home" University environment (0.801), the item was mentioned by $81 \%$ of the respondents;

3rd factor-rather indeterminate (vague and not concrete) information regarding existing practices, principles and standards in force related to non-formal activities assessment and evaluation within the formal learning academic context (0.797), the item was mentioned by $78 \%$ of the respondents;

$4^{\text {th }}$ factor-lack of information specifying the fact how law and foreign language integrated skills could match the employers' requirements relating to various legal labor market spheres $(0.787)$, the item was mentioned by $77 \%$ of the respondents.

The above factors percentage showed no respondents' particular opinions in regard to students' gender $(\mathrm{p}>0.01)$, cultural ( $p>0.01$ ), ethnic attributions ( $p>0.01)$, social background $(\mathrm{p}>0.01)$, geographical origin $(\mathrm{p}>0.01)$, family income $(\mathrm{p}>0.01)$.

\subsection{Benefits from Non-formal Law and Language Integrated Learning as Perceived by Students}

According to the factor analysis, the following list has been arranged concerning non-formal Law and Language Integrated Learning benefits (the list is arranged in descending order of items importance, according to students' opinions):

1st factor-student's involvement in quasi real world professional situations when learning a foreign language, action skills and patterns of behavior in legal settings in a foreign language (0.938), 94\% of the respondents mentioned the item;

2nd factor-opportunity to find and choose the mode of non-formal learning activities that meet students' interests best regarding future fields of professional activities ( 0.840$)$, the item was mentioned by $82 \%$ of the respondents;

3rd factor-opportunity to meet law and language professionals, to get aware of their skills and competences in "live" settings (0.734), the item was mentioned by $74 \%$ of the respondents;

4th factor-opportunity to get aware of plenty of ICT sources that matter in terms of creating individually meaningful legal knowledge in a foreign language ( 0.701$)$, the item was mentioned by $69 \%$ of the respondents;

$5^{\text {th }}$ factor-opportunity to get teacher's advice and guidance tailored to student's particular needs $(0.688)$, the item was mentioned by $66 \%$ of the respondents;

$6^{\text {th }}$ factor-opportunity to get external evaluation from outside university community regarding students' law and language skills $(0.654)$, the item was mentioned by $63 \%$ of the respondents.

The above factors percentage showed no respondents' particular opinions with regard to students' gender $(p>0.01)$, cultural affiliation ( $>0.01)$, ethnic attributions $(p>0.01)$, age $(p>0.01)$, geographical origin $(p>0.01)$, family income ( $>0.01)$.

\subsection{Non-Formal Law and Language Integrated Learning Forms from Which Students Benefited Most}

The factor analysis helped to identify those points the students considered as the most beneficial ones (the list is arranged in descending order of items importance, according to students' opinions):

$1^{\text {st }}$ factor-student's involvement in legal projects that were conducted in foreign language (participation in contests and conferences for law students in foreign languages, in volunteer projects on legal translation/ 
interpretation), (0.921), $92 \%$ of the respondents mentioned the item;

$2^{\text {nd }}$ factor-preparing for international exams in foreign languages (only B1-B2 levels), and doing on-line course in Legal Language (0.740), the item was mentioned by $73 \%$ of the respondents;

$3^{\text {rd }}$ factor-guiding foreign guests that arrive at the university to collaborate in law-related activities $(0.715)$, the item were mentioned by $69 \%$ of the respondents;

$4^{\text {th }}$ factor-student's engagement in volunteer projects to serve the international forums on Law $(0.663)$, the item was mentioned by $64 \%$ of the respondents);

$5^{\text {th }}$ factor-preparing and holding master classes in Foreign Languages for schoolchildren from secondary schools that participate in the program of prior professional knowledge orientation development $(0.501)$, the item was mentioned by $48 \%$ of the respondents;

$6^{\text {th }}$ factor-participation in theme-focused events held in foreign languages $(0.302)$, the item was mentioned by $27 \%$ of the respondents;

The above factors percentage showed no respondents' particular opinions subject to students' gender $(\mathrm{p}>0.01)$, cultural $(p>0.01)$, ethnic attributions $(p>0.01)$, age $(p>0.01)$, geographical origin $(p>0.01)$, family income $(\mathrm{p}>0.01)$.

\section{Discussion}

The research findings provide reasonable grounds for discussing the benefits and challenges that the non-formal law and language integrated learning might bring to university students.

The pilot training has proved that non-formal learning in the integrated law and language context contributes to students' academic progress within the formal academic context that covers both legal knowledge and foreign legal language skills. It can be explained by a number of benefits that non-formal law and language integrated learning provides for students.

First of all, non-formal law and language integrated learning accumulates wider and more varied learning objects, the above objects are more diversified as they are selected by the students themselves in line with their current legal profession-oriented activities. Thus, the students tailor the non-formal learning materials to their individual needs regarding legal branches, theoretical knowledge, foreign language skills and abilities and study the material in a more consistent way.

Furthermore, non-formal law and language integrated learning provides more individualized guidance from the teacher on law and language issues thus bridging the gap in student's law and language integrated professional competence.

Further, due to non-formal law and language learning through participation in conferences, legal contests, legal translation and interpretation projects students get wider professional experience in various legal fields. Students have the opportunity to better understand their aptitude to and competencies in various legal settings. This in turn allows them to percept what spheres of professional activities they might fit most. These findings go in line with the previous statements concerning non-formal learning values in terms of students' self-perceptions on their needs as tailored to further professional world realities (Novosadova et al., 2008).

Moreover, students' involvement in the above real world-based professional activities within non-formal law and language integrated learning have the opportunity to see the ways legal professionals perform their duties and responsibilities, applying law and legal language skills; so, students get aware of particular features regarding lawyers' competences required in multilingual professional settings.

Besides, through non-formal learning students build up their collection of foreign language-based legal sources that they use further on within the formal learning context for academic studies, project work, and legal practice.

Finally, the external evaluation of law and language experts from outside university community regarding students' law and language skills contribute to the students' awareness of tough labor market requirements for university graduates to be more competitive.

The above findings support the prior research statement in respect of informal learning context as fostering the learning context personalization and professionalization (Coroama, 2011; Redecker et al., 2011) and specifies the ways to individualize learning and meet students' needs regarding real life situations within the university academic framework.

The questionnaires made it possible to identify the non-formal law and language learning modes that contribute most to the students' academic progress within the formal learning. Legal projects in a foreign legal language 
turned out to be most beneficial (legal contests and conferences for law students in foreign languages, volunteer projects on legal translation/interpretation) as they enhanced students' awareness of competence requirements regarding foreign language-based professional activities in the legal field.

According to students' opinions, the preparation for the international foreign languages exams for B1-B2 levels was useful in terms of structuring and improving general foreign language knowledge (if sitting general language exams) or legal language skills (if sitting legal language exams) and obtaining language certificates, as well. The students also appreciated on-line courses in Legal Language as the relevant activities ended up with the certificates of achievement that proved the student's competence in performing professional activities in a foreign language and this happened to be a real plus for major students when applying for a legal job.

The fact that non-formal learning through volunteering at international law forums was also appreciated by the students can be explained due to the opportunity for students to develop their skills related to foreign language-based social interaction concerning an official collaboration in the settings that focus on legal practice and theory-oriented research. Students mentioned that the involvement in the above activities helped them identify their future field concerning further MA specialization choice, shape their MA research trajectory, and collect preliminary up-to date research database in a foreign language to strengthen the comparative focus in their legal studies.

The students' involvement in arranging master classes in foreign languages for schoolchildren from secondary schools that participate in the program of prior professional knowledge orientation development helped students to identify their potential interest in the coaching/teaching legal skills in a foreign language. On the contrary, some students mentioned they revealed they would not like to be involved in the above activities either in the mother tongue or in a foreign language. As far as the above non-formal learning mode is concerned students mentioned they got better understanding of their teachers' activities, requirements, behavior, etc. The above contributes to deeper and more detailed mutual understanding between the student and the teacher and fosters their collaboration within the formal academic learning.

As to the theme-focused events in foreign languages, the interviews and questionnaires have revealed that students view the above as a way to improve their social and cultural skills in a foreign language. Besides, learners appreciate the respective activities to combine work and pleasure, to lessen load and stress of the formal academic studies due to strict regulations regarding rigorous terms of tasks performance and submission, etc.

The above modes of non-formal activities that have been identified through research as most effective ones help identify concrete ways to redesign a university curriculum with the view to strengthen "work-integrated approach to student learning" the necessity for which has been outlined in prior studies (Chester et al., 2005).

The importance of ICT support for non-formal learning should not be underestimated, as well. Besides the fact that have been mentioned in the literature review section, the experiment revealed that technology not only supports educational communication and in group activities, but helps students to search for and select sources with the view to create individually meaningful knowledge in a foreign language in a particular domain of professional activities. Thus, ICT needs special emphasis through non-formal learning in terms of the technology didactic potential regarding content and language integrated non-formal learning.

When considering challenges that students mentioned it appears well timed to underline that non-formal learning essence, possible forms, their specific features and diverse benefits (that have been identified throughout the observation and described at the beginning of the section) should be explained to students prior to their involvement in non-formal learning.

Judging by the surveys it appears to be of current importance to point out that students should be informed by the teaching staff and formal academic programs' coordinators (tutors) in a systematized and comprehensive way about all possible trajectories and activities for non-formal learning both at the home university and within the outside professional world. The experiment has revealed that academic studies just gain from such an approach and relevant information provision.

What is more, principles of the students' non-formal learning activities evaluation and recognition as part of the university formal learning framework should be elaborated, put in line with the university formal learning requirements and made public for the students. The present research findings in this respect support the relevant theoretical provisions, specified previously by scholars (Colardyn \& Bjornavold, 2004).

Finally, the lack of information specifying the list of law and language skills meeting the employers' requirements in respect to various legal labor market spheres decreases the university overall potential and opportunities to get graduates hired and employed in accordance with university degree and qualification. 
The research findings support scholars' prior statements regarding formal, non-formal and informal interdependence in education (Melnic \& Botez 2014) and specify the essence of the interdependence between formal and non-formal learning when domain specific content and language integrated learning is in the focus.

Special emphasis should be laid on the issue of the variables that were determined for statistical data processing. As it was mentioned in section 2.2. The variables were specified according to common educational research practices. Nonetheless, the above variables turned out to bear no statistical significance for research findings as those non-formal Law and Language integrated learning challenges and benefits that were identified throughout the research did not reveal any correlation with the above variables. It means that further research with possible choice of significant variables (students' year of academic studies, i.e. $2^{\text {nd }}, 3^{\text {rd }}, 4^{\text {th }}$ year of BA academic studies, university graduates and MA students, employers) has become a necessity. The assumption relies on those researchers' opinions that underline the interdependence between non-formal learning efficiency and the level of learner's awareness of future profession requirements as well as the learner's skills to learn by experience rather than the learner's cultural affiliation, family background, gender, etc. (Cabezudo et al., 2008).

\section{Conclusion and Recommendations}

Non-formal law and language integrated learning within university formal environment contributes to fostering profession-oriented approach to students' academic studies within the university framework.

The learning mode under studies should be mapped within the university curriculum and subjects syllabus in terms of recommended non-formal activities list, workload calculation, documentary proof, evaluation criteria.

The possible list of non-formal activities content and language integrated learning might vary in view of a concrete field of graduates' future profession. Each particular field of graduates' specialization might require further studies in the field.

Special emphasis should be laid on non-formal assignments that could pave the way to enhancing students' creativity, critical thinking, and knowledge personalization.

The faculty staff should coordinate their policies regarding students' non-formal learning in order to avoid learners' overload with extra curriculum assignments, their possible inconsistency, etc.

Students should be provided with relevant information about up-to-day informal learning trajectories.

Further research should involve graduates and employers' interviews with respect to the topical importance of skills and activities within non-formal learning activities for students of various degree programs.

\section{References}

Ainsworth, H. L., \& Eaton, S. E. (2010). Formal, Non-formal and Informal Learning in the Sciences.

Anderson, J. R., Reder, L. M. \& Simon, H. A. (1996). Situated learning and education, Educational Researcher, 25(4), 5-11. http://dx.doi.org/10.3102/0013189X025004005

Boud, D., Cohen, R., \& Walker, D. (2000). Understanding learning from experience. In D. Boud, R. Cohen, \& D. Walker (Eds.), Using experience for learning (pp. 8-17). UK, Milton Keynes: Open University Press.

Bowman, K., Clayton, B., Bateman, A., Knight, B., Thomson, P., Hargreaves, J., . . . Enders, M. (2003). Recognition of Prior Learning in the Vocational Education and Training Sector. Adelaide: NCVER.

Brockbank, A., \& Magill, I. (2007). Facilitating reflective learning in higher education (2nd ed.). UK: London: Open University Press.

Cabezudo, A., Christidis, C., Carvalho da Silva, M., Valentina Demetriadou-Saltet, V., Halbartschlager, F., \& Mihai, G.-P. (2008). Global Education Guidelines. Lisbon: North-South Centre of the Council of Europe.

Carron, G., \& Carr-Hill, R. A. (1991). Non-formal Education: Information and Planning Issues. Paris: International Institute for Educational Planning, UNESCO 80.

CEDEFOP. (2009). Making learning visible: Identification, assessment and recognition of non-formal learning in Europe. Retrieved from http://www.cedefop.europa.eu/en/publications-and-resources/publications/3013

Chester, K. M., Moon, K., Hsia, P., Chan, S., Choi, K., Chan, L., . . . Chang, J. (2005). Re-designing a curriculum that values a work-integrated approach to student learning. Developments in Business Simulations and Experiential Learning, 32, 307-314.

Colardyn, D., \& Bjornavold, J. (2004). Validation of Formal, Non-Formal and Informal Learning: Policy and practices in EU Member States. European Journal of Education, 39(1), 69-89. http://dx.doi.org/10.1111/j.0141-8211.2004.00167.x 
Colley, H., Hodkinson, P., \& Malcolm, J. (2002). Non-formal Learning: Mapping the Conceptual Terrain. A Consultation Report. Leeds: University of Leeds Lifelong Learning Institute. Retrieved from $\mathrm{http}$ //www.infed.org/archives/e-texts/colley_informal_learning.htm

Coroama, L. I. (2011). Reconsidering the Relation between the Formal and Informal Learning of the English Language in the Higher Education System. Retrieved from http://euromentor.ucdc.ro/dec2011/en/reconsideringtherelationbetweentheformallauraioanacoroma_8.pdf

Coyle, D., Hood, Ph., \& Marsh, D. (2010). CLIL. Content and Language Integrated Learning. Cambridge: Cambridge University Press

Cushion, C., Nelson, L., Armour, K., Lyle, J., Jones, R., Sandford, R., \& O’Callaghan, C. (2010). Coach Learning and Development: A Review of Literature. Retrieved from https://www.sportscoachuk.org/sites/default/files/Coach\%20Learning\%20and\%20Dev\%20Review.pdf

Damesin, R., Fayolle, J., Fleury, N., Malaquin M., \& Rode, N. (2014). Challenges, actors and practices of non-formal and informal learning and its validation in Europe. Brussels, European Trade Union Institute (ETUI).

Dehnbostel, P., \& Molzberger, G. (2006). Combination of formal learning and learning by experience. In J. N. Streumer (Ed.), Work-related learning (pp. 51-69). Rotterdam: Springer.

Dodds, T. (1996). The use of distance learning in non-formal education. Vancouver: Commonwealth of Learning/Cambridge, UK: International Extension College. Retrieved from http://www.col.org/PublicationDocuments/pub_Use_of_DE_in_NonFormal_Ed_Dodds_T.pdf

Doiz, A., Lasagbaster, D., \& Sierra, J. M. (Eds.). (2013). English-Medium Instruction at Universities: Global Challenges. Bristol/Buffalo/Toronto: Multilingual Matters.

Dumitrescu, C. (1999). Non-formal education. Report. Committee on Culture and Education. Retrieved from $\mathrm{http} / / /$ assembly.coe.int/nw/xml/XRef/X2H-Xref-ViewHTML.asp?FileID=8807\&lang=en

Eaton, S. E. (2011). Formal, Non-Formal and Informal Learning: The Case of Literacy, Essential Skills and Language Learning in Canada. Retrieved from http://www.infed.org/archives/e-texts/eaton_literacy_ languages_and_types_of_learning.pdf

Eraut, M. (2000). Non-formal Learning, Implicit Learning and Tacit Knowledge in Professional Work. In F. Coffield (Ed.), The Necessity of Informal Learning. Bristol: Policy Press.

European Centre for the Development of Vocational Training. (2014). Skill mismatch: more than meets the eye. Cedefop.

Federal Law “On Education in Russian Federation”. (2012). Federal Law № 273, 29.12.2012. Retrieved from http://nic.gov.ru/en/docs/russian/laws/about_education_in_russia

Fokienè, A., \& Sajienè, L. (2009). Portfolio method in assessment of non-formal and informal learning achievements. The Quality of Higher Education, 6. Kaunas: Vytautas Magnus University.

Fortanet-Gomez, I. (2013). CLIL in Higher EducationTowards a Multilingual Language Policy. Bristol: Multilingual matters.

Fraser, W. (1995). Learning from experience. Leicester: NIACE.

Hodkinson, P., Colley, H., \& Malcolm, J. (2003). The Interrelationships between Informal and Formal Learning. Journal of Workplace Learning, 15, 313-318. http://dx.doi.org/10.1108/13665620310504783

Latchem, C. (2014). Informal Learning and Non-Formal Education for Development. Journal of Learning for Development, 1(1). Retrieved from http://www.j14d.org/index.php/ej14d/article/view/6/6

Lindquist, K. (2012). Learning non-formally via online CLIL. Retrieved from http://aeclil.altervista.org/Sito/wp-content/uploads/2012/12/WP6_Del28.33-NFE-Learning-informally-via-o nline-CLIL.pdf

Livingstone, D. W. (2001). Adults Informal Learning: Definitions, Findings, Gaps and Future Research. NALL Working Paper \# 21-2001. \# Retrieved http://www.oise.utoronto.ca/depts/sese/csew/nall/res/21adultsifnormallearning.htm

Marsh, D. (1994). Bilingual Education \& Content and Language Integrated Learning. Paris: International Association for Cross-cultural Communication, Language Teaching in the Member States of the European Union (Lingua), University of Sorbonne. 
Marsh, D., Mehisto, P., Wolff, D., \& Frigols-Martín, M. J. (2011). European Framework for CLIL Teacher Education. European Centre for modern Languages. Retrieved from http://clil-cd.ecml.at/LinkClick.aspx? fileticket $=\mathrm{C} 0 \mathrm{kUO} \% 2 \mathrm{BvEc} 6 \mathrm{k} \% 3 \mathrm{D} \&$ tabid $=2254$ \&language $=\mathrm{en}-\mathrm{GB}$

Melnic, A.-S., \& Botez, N. (2014). Formal, Non-Formal and Informal Interdependence in Education. Economy Transdisciplinarity Cognition, 17(1), 113-118.

Misko, J. (2008). Combining formal, non-formal and informal learning for workforce skill development. Australia: Australian Industry Group.

Naves, T. (2009). Effective content and language integrated learning (CLIL) programmes. In Y. Ruiz de Zarobe, \& R. Jimenez (Eds.), Catalan, Content and language integrated learning: Evidence from research in Europe (pp. 22-40). Bristol: Multilingual matters.

Nelson, L. J., Cushion, C. J., \& Potrac, P. (2006). Formal, non-formal and informal coach learning: A holistic conceptualization. International Journal of Sports Science and Coaching, 1(3), 247-259.

Novosadova, M. et al. (2008). NFE Book. The Impact of Non-Formal Education on Young People and Society. Brussels. AEGEE. Retrieved from http://www.aegee.org/wp-content/uploads/publications/NFE_book.pdf

Oleynikova, O. (2014). Prerequisites for developing and implementing the national qualification system. The Education and Science Journal, 5, 4-13.

Reason, R. D. (2003). Student Variables that Predict Retention: Recent Research and New Developments. NASPA Journal, 40(4), 172-191. http://dx.doi.org/10.2202/0027-6014.1286

Redecker, C., Leis, M., Leendertse, M., Punie, Y., Gijsbers, G., Kirschner, P., . . Hoogveld, B. (2011). The Future of Learning: Preparing for Change. Retrieved from http://ipts.jrc.ec.europa.eu/publications/pub.cfm?id=4719

Redvers-Lee, P. (2002). Is Non-formal Education in Latin America: Good for the Poor? Retrieved from $\mathrm{http}$ //escotet.org/in-focus/open-forum/is-non-formal-education-in-latin-america-good-for-the-poor/

Schugurensky, D. (2000). The Forms of Informal Learning: Towards a Conceptualization of the Field, NALL Working Paper \#19-2000. Retrieved from http://www.oise.utoronto.ca/depts/sese/csew/nall/res/19formsofinformal.htm

Sergeev N. (2013). University pedagogical education under today's conditions. Russian Education and Society, 55(2), 82-97. http://dx.doi.org/10.2753/RES1060-9393550204

Singh, M. (2009). Why Recognition Matters-Valuing Informal and Non-formal Learning across the North-South Divide. Hamburg.

Smit, U., \& Dafouz, E. (2012). Integrating content and language in higher education. An introduction to English-medium policies, conceptual issues and research practices across Europe. In U. Smit, \& E. Dafouz (Eds.), Integrating Content and Language in Higher Education. Gaining Insights into English-Medium Instruction at European Universities (pp. 1-12). Special Issue of AILA Review 25.

Watanabe, Yoshinori, Makoto, I., \& Shinichi, I. (Eds.). (2011). CLIL (Content and Language Integrated Learning)-New Challenges in Foreign Language Education at Sophia University-Volume 1: Principles and Methodologies. Tokyo: Sophia University Press.

Werquin, P. (2010). Recognising Non-Formal and Informal Learning Outcomes, Policies and Practices: Outcomes, Policies and Practices. OECD Publishing. Retrieved from http://www.oecd.org/education/skills-beyond-school/44600408.pdf

Wilkinson, R. (Ed.). (2004). Integrating content and language: Meeting the challenge of multilingual higher education. Maastricht: Universitaire Press.

Yasunaga, M. (2014). Non-formal Education as a Means to Meet Learning Needs of out-of school Children and Adolescents. UNICEF and UNESCO Institute for Statistics. Retrieved from http://allinschool.org/wp-content/uploads/2015/01/OOSC-2014-Non-formal-education-for-OOSC-final.pdf

Zolotaryova, N. (2014). Developing the vocational training system for the Russian innovative economy. The Education and Science Journal, 5, 14-22. 


\section{Copyrights}

Copyright for this article is retained by the author(s), with first publication rights granted to the journal.

This is an open-access article distributed under the terms and conditions of the Creative Commons Attribution license (http://creativecommons.org/licenses/by/3.0/). 